\title{
Factors Associated with Job Performance of the ICDS Supervisors
}

\author{
Purva Dayya $^{1 *}$, Snehlata Maheshwari ${ }^{2}$ and Bhupendra Upadhyay ${ }^{3}$ \\ ${ }^{1}$ Extension Education and Communication Management, CCAS, MPUAT, Udaipur, India \\ ${ }^{2}$ Director of Extension, DEE, MPUAT, Udaipur, India \\ ${ }^{3}$ Department of Agricultural Statistics and Computer Application, College of Agriculture, \\ MPUAT, Udaipur, India
}

\section{A B S T R A C T}

\begin{tabular}{|c|c|}
\hline $\begin{array}{l}\text { K e y w o r d s } \\
\text { Supervisors, } \\
\text { performance, } \\
\text { Factors and } \\
\text { association }\end{array}$ & $\begin{array}{l}\text { The present study was conducted to know the factors associated with job } \\
\text { performance of the Supervisors. The present study was conducted in } \\
\text { purposively selected Udaipur division of Rajasthan state. The questionnaire } \\
\text { technique was used for collecting data from the respondents. Experience, }\end{array}$ \\
\hline Art & $\begin{array}{l}\text { refresher trainings, knowledge, job satisfaction and constraints of the } \\
\text { respondents were found to have significant association with job }\end{array}$ \\
\hline $\begin{array}{l}\text { Accepted: } \\
\text { 15April } 2019 \\
\text { Available Onli } \\
10 \text { May } 2019\end{array}$ & $\begin{array}{l}\text { performance of the respondents and non significant association was found } \\
\text { between age, education and job training of respondents with job } \\
\text { performance. }\end{array}$ \\
\hline
\end{tabular}

\section{Introduction}

Supervisors play a very important role in ICDS, and their job performance is a very crucial for successful implementation of the scheme. Supervisors plan overall activities and instruct the Anganwadi Workers. The responsibility of Supervisors is to physically visit each Anganwadi Centre (AWC) under her charge at least once a month to ensure that all records are properly maintained, medical kits and supplementary nutrition are supplied as per the needs to each AWC, and that all events are held as planned. According to Manual of NIPCCD 2007, a supervisor when visit to an AWC does not exercise her duty as an inspector only but as a supervising officer.
For any scheme to be effective, it is essential that there should be an adequate knowledge possessed by the functionaries and it should lead to an appropriately performing their job responsibility. The job performance of the Supervisors can be found associated with a number of factors such as age, education, experience on present job, job trainings, refresher trainings, knowledge and constraints. Therefore, an effort was made to study the association of the factors with job performance.

\section{Materials and Methods}

The present study was conducted in purposively selected Udaipur division of 
Rajasthan state which consists of 6 districts namely Banswara, Chittorgarh, Dungarpur, Pratapgarh, Rajsamand and Udaipur. All the Supervisors were included as sample in the study at the time of planning. At the time of data collection, 97 Supervisors were not available due to job shifting, therefore 271 Supervisors were finally included as sample in the study. The questionnaire technique was used for collecting data from the respondents.

\section{Results and Discussion}

Findings regarding factors association with job performance and job satisfaction of the Supervisors are presented in Table 1. This was determined by computing chi square with all the possible factors and job performance and satisfaction of respondents.

\section{Factors associated with job performance of the Supervisors}

The findings presented in Table 1 reveal that non significant association was found between age, education and job training with job performance of the respondents as the calculated chi square values were less than the tabulated values. This indicates that the Supervisors whether young or old age, their job performance was not associated with age.

Similarly majority of the respondents possessed essential qualification and received job training therefore education and job training as factors were also not associated with the job performance of the respondents. Findings get support from the study of Kumari et al., (2017) on "study of role expectation and role performance of lady Supervisors engaged under ICDS at Samastipur district of north Bihar region" that age had non-significant relationship with the dependent variable i.e. role expectation and role performance.
Experience in present job was found to have significant association with job performance of the respondents at 5 per cent level of significance as calculated value 4.61 was greater than the tabulated value. Refresher trainings were also found to have significant association with job performance of the respondents at 1 per cent level of significance as calculated values 21.14 was greater than the tabulated value. The possible reasons for such findings may be that with experience, and refresher trainings there is always possibility of improvement over the existing things/ works so, these factors were found to have significant association with job performance of the Supervisors or job performance depend on experience and refresher training.

Table 1 further reveals that significant association was found between knowledge and job performance of the respondents at 5 per cent level of significance. It is very true that knowledge of job helpful in enhances the job performance therefore job performance depend on knowledge. In depth review of the components of knowledge in Table 1 further reveal that supervision and continuous education was found associated with job performance of the respondents at 1 per cent level of significance whereas the component of planning and organizing trainings was associated with job performance at 5 per cent level of significance. These means job performance of respondents depend on these components of knowledge. The reason for significant association may be that for doing supervision and continuous education and planning and organizing trainings knowledge is required along with creativity to perform or handle varied situations. Findings are also in line with Ghodeshwar (2010) that role performance of Anganwadi Workers (AWWs) in Integrated Child Development Services programme in Baihar block of Balaghat district (M.P.) revealed that 
technical knowledge of Anganwadi Workers were found to have positive significant correlation with the role performance.

The Table 1 also reveals that non significant association was found between the components of planning and administration, service delivery and monitoring and evaluation with job performance of Supervisors of ICDS scheme. This means job performance of Supervisors was not dependent on these components of knowledge. The possible reason behind such findings may be that planning and administration and service delivery tasks were performed along with CDPO/AWW while monitoring and evaluation activity was performed as routine activity with structured pattern of information therefore no need of additional knowledge.

Table.1 Association of factors with job performance

\begin{tabular}{|c|c|c|}
\hline S. No. & Factors & $\chi^{2}$ value \\
\hline 1. & Age & $1.43 \mathrm{NS}$ \\
\hline 2. & Education & $0.31 \mathrm{NS}$ \\
\hline 3. & Experience in present job & $4.61^{*}$ \\
\hline 4. & Job training & $0.39 \mathrm{NS}$ \\
\hline 5. & Refresher trainings & $21.14^{* * *}$ \\
\hline 6. & Knowledge & $4.19^{*}$ \\
\hline a. & Planning and administration & $1.05 \mathrm{NS}$ \\
\hline b. & Supervision and continuous education & $12.31^{* * *}$ \\
\hline c. & Planning and organizing trainings & $4.39^{*}$ \\
\hline d. & Service delivery & $0.53 \mathrm{NS}$ \\
\hline e. & Monitoring and evaluation & $3.62 \mathrm{NS}$ \\
\hline 7. & Job satisfaction & $16.6^{* *}$ \\
\hline a. & Administrative job & $3.05 \mathrm{NS}$ \\
\hline b. & Work place & $4.15^{*}$ \\
\hline c. & Nature of the job & $2.69 \mathrm{NS}$ \\
\hline d. & Interpersonal relationship & $10.04^{* * *}$ \\
\hline e. & Facilities & $53.82^{* *}$ \\
\hline 8. & Constraints & $3.99^{*}$ \\
\hline a. & Personal constraints & $0.32 \mathrm{NS}$ \\
\hline b. & Administrative constraints & $11.68^{* *}$ \\
\hline c. & Social constraints & $0.09 \mathrm{NS}$ \\
\hline d. & Technical constraints & $10.78^{* * *}$ \\
\hline e. & Financial constraints & $3.39 \mathrm{NS}$ \\
\hline f. & Operational constraints & $5.31^{*}$ \\
\hline
\end{tabular}

$*=$ Significant at 5 per cent level of significance

** = Significant at 1 per cent level of significance

NS $=$ Non Significant

In Table 1 job satisfaction was found associated with job performance of the respondents at 1 per cent level of significance as calculated value 16.6 was greater than tabulated value. This means job performance depends on job satisfaction. This may be due 
to the reason that person's satisfied with job put best efforts in the job. In view of components of job satisfaction the Table further reveal that work place, interpersonal relationship and facilities were found associated with job performance of the respondents at 5 per cent level of significance. This means job performance very much depends on these components of job satisfaction. It is assume that personnel require proper work place with good interpersonal relationship and proper facility for proper job performance. The administrative job and nature of job were not found to have association with job performance of the respondents as calculated value 3.05 and 2.69 were less than the tabulated values. This means job performance does not depend on these job satisfaction components.

The constraints were found associated with job performance of the respondents at 5 per cent level of significance as the calculated value 3.99 was more than the tabulated value. This means job performance of the respondents is very much dependent on constraints. As with constraints nobody can perform better and with full potential. In depth review of various aspects of constraints, administrative, technical and operational aspects were found associated with job performance of the respondents. While personal, social and financial constraints were not found associated with job performance of the respondents. This means job performance depends on administrative, technical and operational constraints while job performance does not depend on personal, social and financial constraints. The reason for such findings may be that all official constraints related to job affect the job performance while personal and social constraints are individual own constraints and they have to handle it. Regarding the non significant association with job performance it can be said that ICDS scheme is well established scheme of government so, in general for the ICDS activities, no financial constraint might be there so non significant association was framed with job performance of the respondents.

\section{References}

Ghodeshwar, R., 2010. A study on role performance of Anganwadi Workers (AWWs) in Integrated Child Development Services (ICDS) Programme in Baihar block of Balaghat district (M.P.). M.Sc. Thesis submitted to Jawaharlal Nehru Krishi Vishwa Vidyalaya, Jabalpur.

Kumari, R., Singh, M. and Paswan, A.K. 2017. Role expectation and role performance of lady supervisors under ICDS. International journal of Home Science Extension and Communication Management. 4(1): 53-56.

Manual of NIPCCD, 2007.Course curriculum of primary training for Supervisors. The Integrated Child Development Services, New Delhi, 3-4. Retrieved from

http://www.nipccd.nic.in/doc.htm.on 20/5/2017.

\section{How to cite this article:}

Purva Dayya, Snehlata Maheshwari and Bhupendra Upadhyay. 2019. Factors Associated with Job Performance of the ICDS Supervisors. Int.J.Curr.Microbiol.App.Sci. 8(05): 1748-1751. doi: https://doi.org/10.20546/ijcmas.2019.805.201 